to complete their studies. Not more than 10 per cent of the places available may be filled by those of age 18-19 recommended for deferment by joint recruiting boards, and other suitable students of that age-group. Medical, dental and veterinary students will in future be dealt with in the same way as other students. Women's colleges are being asked to give preference to those who have been on war service. It is hoped that universities generally will not accept boys younger than eighteen. Mr. Isaacs added that these proposals have been accepted by the vice-chancellors of the universities.

For many months past, this announcement has been anxiously awaited by those responsible for university development in Britain. Since Mr. Isaacs stated that the vice-chancellors of the universities generally approve the scheme, it would seem that university needs have, in the main, been met. It is clearly right that those whose courses have been interrupted, and those who would have entered the universities had the War not intervened and diverted them to some form of national service, should have preference in the competition for places. But without studying the data on the possible number of entries, it is not possible to assess the wisdom of fixing on the figure of 10 per cent for the maximum number of places available for schools. It is probably all to the good, however, that the entry of youths of less than eighteen should be discouraged; they will thus be able to enter the universities at a more mature age and with a period of service intervening between their school and university studies. The proposal to open up all subjects again will be widely welcomed; there has been a serious break in the output of students of the humanities which is likely to show its effect in the teaching profession for some years to come, and indirectly it has militated against that broad cultural education which should characterize university training.

\section{Series of Polynomials}

IN many problems of pure and applied mathematics it is required to express a given function in terms of certain polynomials, such as those associated with the names of Legendre and Hermite. The general theory of all polynomials that can be used in this way engaged the attention of several mathematicians, including Prof. J. M. Whittaker of Liverpool. In the dark days of 1942-43 Major Whittaker, as he was then, found himself stationed in the vicinity of the University of Cairo. Stimulated by contact with the active mathematicians of that University, he started to deliver a course of lectures on the subject of his peace-time research. The course was cut short when he was transferred to another theatre of war. The lectures delivered were edited by Prof. Mursi, of the Fouad I University, Cairo, and published in pamphlet form by the Faculty of Science of that University. They deal with simple and other basic series, Cannon series, series effective on a circle, representation near a point, algebraic theory (using matrices), uniqueness, convergence, integral functions, and successive derivatives.

\section{Resistance Welders and the Electricity Supply Industry}

IN a recently published paper on this subject $(J$. Inst. Elec. Eng., 92, Part 2, No. 30; Dec. 1945) the author, R. B. Giles, is primarily concerned with the effect of the A.c. resistance welder upon the networks of public supply authorities and the problem of securing an equitable revenue for the service rendered to the user. To that end, the electrical characteristics of the welding machine are detailed, together with some particulars of experience and consumption of energy in the metal trades, both of Great Britain and of the United States. There is a brief reference to the D.C. capacitance-storage welder, which is of comparatively recent development, and some details of the energy used by this type of machine are given. Proposals are made for a standard specification for the use of welder manufacturers and for the more satisfactory guidance of the supply authority and the user. The possibilities of a special tariff for welder consumers are also discussed.

\section{Society for Endocrinology}

Contributors to the Journal of Endocrinology have recently taken the initiative in the formation of a Society for Endocrinology, the object of which is to promote the advance of endocrinology by observational, experimental and clinical studies. The Society was founded at an inaugural meeting held at Guy's Hospital, London, on April 26, when the following elections were made: Hon. Secretary, Dr. S. J. Folley; Hon. Treasurer, Dr. C. W. Emmens; Hon. Editor of the Society's Proceedings, Prof. S. Zuckerman; Members of Committee, Dr. P. M. F. Bishop, Dr. A. S. Parkes, Mr. P. C. Williams, Prof. F. G. Young. In addition to ordinary meetings at which original scientific communications will be presented, the Society hopes to organise from time to time symposia on selected topics in the field of endocrinology. The address of the Hon. Secretary is : c/o The National Institute for Research in Dairying, Shinfield, near Reading.

\section{Society for the Study of Evolution}

A Society for the Study of Evolution was formed on March 30, 1946, on the occasion of the meeting of the American Association for the Advancement of Science at St. Louis. The object of the Society is the promotion of the study of organic evolution and the integration of the various fields of biology, such as taxonomy, palæontology, geneties, that are interested in evolution. The elected officers are: President : Dr. George G. Simpson; Vice-Presidents : Prof. Ernest B. Babcock, Prof. A. E. Emerson, and Prof. J. T. Patterson; Secretary: Dr. Ernst Mayr; Treasurer: Mr. K. P. Schmidt; Council: Prof. R. Chaney, Prof. Th. Dobzhansky, Prof. E. R. Dunn, Prof. G. Jepsen, Prof. H. J. Muller, and Prof. Sewall Wright. Communications should be addressed to the secretary, Dr. Ernst Mayr, American Museum of Natural History, Central Park West at 79th Street, New York 24, New York.

\section{Society of Glass Technology}

According to the report for 1945 of the Council of the Society of Glass Technology, presented at the annual general meeting held at Sheffield on April 25, there are now an Indian Section and five local sections, in addition to the parent body. The total membership exceeds one thousand, distributed through thirty-five countries. Prof. H. Moore retired from the presidency, after holding office for two years, and was succeeded by Mr. Geoffrey I. C. Marchand, director of the Glass Manufacturers' Federation. Prof. W. E. S. Turner, honorary general secretary, will retire on May 31, and Dr. J. H. Partridge, of the Research Laboratories 